\title{
Anatomic variations of the liver surface detected by the multidedector computed tomography
}

\section{Karaciğer yüzeyinin multidedektör bilgisayarlı tomografiyle saptanan anatomik varyasyonlart}

\author{
Mehmet Haydar Atalar*, İsmail Şalk \\ Department of Radiology (Assoc. Prof. M. H. Atalar, MD., Assist. Prof. İ. Şalk, MD), Cumhuriyet \\ University School of Medicine, TR-58140 Sivas
}

Geliş tarihi/Received: April 05, 2013; Kabul tarihi/Accepted: May 20, 2013

\section{*Corresponding author:}

Dr. Mehmet Haydar Atalar, Radyoloji Anabilim Dalı, Cumhuriyet Üniversitesi Tıp Fakültesi, TR58140 Sivas. E-mail: mhatalar@gmail.com

To the editor

Proper identification of anatomic variations within the upper abdomen is essential for surgical and radiological interventions. Similar to the soft tissues in other parts of the body, abdominal muscles can show degenerative changes with ageing [1-4].

A 58-year-old woman who had undergone surgery for ovarian cancer in the previous year was admitted to our hospital for a routine follow-up. On her last admission, a contrastenhanced abdominal CT obtained for a routine protocol showed a soft-tissue nodule lateral to the liver that mimics a peritoneal implant. This nodule appeared, on serial images, in continuity with a typical diaphragmatic slip. Additionally, CT scan showed superficial accessory fissure on lateral aspect of liver dome containing fat and linear density (Figure 1). As a result, the peritoneal implant-like appearance on the lateral aspects of the liver dome was interpreted as age-related diaphragmatic muscle change.

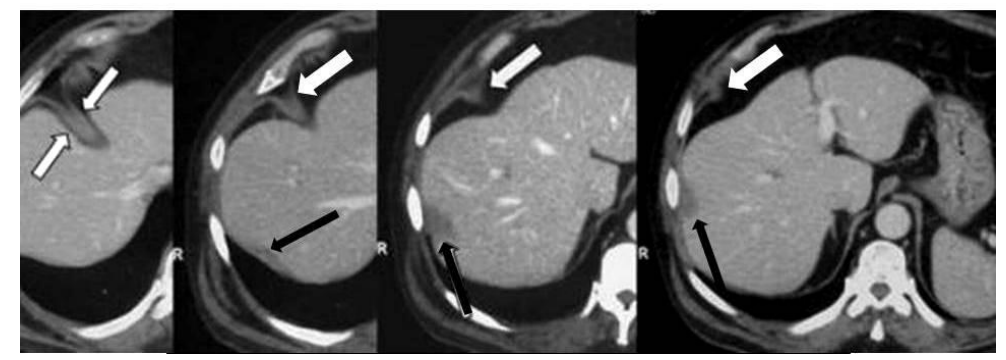

Figure 1. Montage of four axial contrast-enhanced portal venous phase CT images demonstrate from superior to inferior shows the apparent nodular mass (thin black arrows) is in curvilinear continuity with the diaphragm, confirming the structure is a prominent diaphragmatic slip. In addition, CT scans show superficial accessory fissure on lateral aspect of liver dome containing fat and linear density (thick white arrows).

Prominent muscular slips of the diaphragm may be seen as soft-tissue nodules in contiguity with the diaphragm on sectional imaging modalities [1, 3]. Prominent diaphragmatic slips may mimic perihepatic metastatic peritoneal implants, resulting in unnecessary follow-up investigations and patient anxiety. Prominent diaphragmatic slips are described as being more frequent in deep inspiration. Such diaphragmatic pseudotumors are also commoner in elderly or emphysematous patients. The distinction of prominent diaphragmatic slips from true peritoneal implants is based on their 
continuity peripherally with the diaphragm, curvilinear course when tracked over serial slices, and separation from adjacent viscera by subdiaphragmatic fat. If a question stil remains, decubitus and expiratory $\mathrm{CT}$ sections are also said to help. On expiration, the the nodular diaphragmatic slip will decrease in size [1-5].

Accessory hepatic fissures, unlike the major fissures, are limited to the superior aspect of the liver near the diaphragmatic dome $[2,3]$. They are formed by the invagination of the muscular diaphragm into the liver. This occurs most commonly in the superior aspect of the right lobe of the liver and is common in elderly patients, as in our case. Accessory hepatic fissures can be single or multiple, giving a scalloped appearance to the liver. Subdiaphragmatic fat and the peritoneum accompany the muscular diaphragm in the accessory fissure, and, therefore, when ascites is present, it can extend into the accessory fissures. On sectional imaging modalities, the accessory fissures are seen as single or multiple thin lines projecting inward from the periphery of the liver [1-5].

In conclusion, surgeons, gastroenterologists and radiologists should be aware of the presence of these variations to avoid serious or fatal complications.

\section{References}

1. Rosen A, Auh YH, Rubenstein WA, Engel IA, Whalen JP, Kazam E. CT appearance of diaphragmatic pseudotumors. J Comput Assist Tomogr 1983; 7: 995-9.

2. Schwartz EE, Wechsler RJ. Diaphragmatic and paradiaphragmatic tumors and pseudotumors. J Thorac Imaging 1989; 4: 19-28.

3. Macchi V, Feltrin G, Parenti A, De Caro R. Diaphragmatic sulci and portal fissures. J Anat 2003; 202: 303-8.

4. Parienty RA, Marichez M, Pradel J, Parienty I, Demange P. Pararenal pseudotumors of the diaphragm: Computed tomographic features. Gastrointest Radiol 1987; 12: 131-3.

5. Joshi SD, Joshi SS, Athavale SA. Some interesting observations on the surface features of the liver and their clinical implications. Singapore Med J 2009; 50: 715-9. 